INOBIS: Jurnal Inovasi Bisnis dan Manajemen Indonesia

Volume 1, Nomor 1, Desember 2017

Andhy Setyawan

\title{
Pembingkaian Pesan dan Perubahan Fungsi Utilitas Konsumen Produk Ramah Lingkungan: Sebuah Rerangka Konseptual
}

\author{
Andhy Setyawan \\ Mahasiswa Program Doktor Ilmu Manajemen, Universitas Brawijaya; \\ Dosen pada Jurusan Manajemen, FBE Universitas Surabaya \\ andhy@staff.ubaya.ac.id
}

\begin{abstract}
Abstrak
Terdapat irisan yang besar antara teori ekonomi dan ilmu manajemen dalam hal perilaku konsumen. Banyak konsep teori ekonomi yang diterapkan dalam menganalisis perilaku konsumen. Perilaku konsumen sangat erat kaitannya dengan teori utilitas, yang merupakan salah satu teori penting dalam ilmu ekonomi. Konsumen cenderung memilih produk yang memberikan nilai utilitas atau manfaat yang maksimal. Berkaitan dengan isu keberlanjutan lingkungan hidup, konsumen diperhadapkan pada produk yang ramah lingkungan disamping produk konvensional yang ada. Masih rendahnya konsumsi produk ramah lingkungan dibandingkan produk konvensional merupakan salah satu masalah praktis yang dihadapi pemasar dalam area pemasaran produk ramah lingkungan. Penulisan artikel ini bertujuan memberikan rerangka konseptual untuk meningkatkan persepsi utilitas konsumen pada produk ramah lingkungan melalui pembingkaian pesan dalam komunikasi pemasaran. Telaah pustaka mengenai pembingkaian pesan pada peningkatan persepsi utilitas konsumen produk ramah lingkungan menjadi diskusi utama dalam artikel ini. Pembingkaian pesan merupakan salah satu cara yang dapat dilakukan pemasar untuk merubah preferensi konsumen dari produk konvensional menjadi produk ramah lingkungan dengan meningkatkan persepsi utilitas konsumen.
\end{abstract}

Kata kunci : perilaku konsumen, utilitas, pembingkaian pesan, produk ramah lingkungan

\section{Pendahuluan}

Permasalahan mengenai kerusakan lingkungan hidup dan dampaknya bagi keberlanjutan hidup manusia merupakan salah satu isu penting yang menjadi perhatian para akademisi, pemerintah, maupun organisasi dunia (Haytko \& Matulich, 2008). Steg dan Vlek (2009) berpendapat bahwa kualitas lingkungan hidup sangat bergantung pada pola perilaku manusia. Perilaku manusia dapat menyebabkan kerusakan yang serius pada lingkungan bumi serta turut mengancam kehidupan manusia dan spesies lainnya di masa yang akan datang (Lehman \& Geller, 2004). Mendleson dan Polonsky (1995) menyatakan bahwa tren mengenai kepedulian terhadap lingkungan hidup sudah mengubah perilaku dan permintaan konsumen terhadap produk yang ramah lingkungan.

Meningkatnya kesadaran konsumen pada isu-isu kesehatan dan lingkungan hidup telah meningkatkan konsumsi pada produk ramah lingkungan maupun produk pangan organik dalam beberapa tahun terakhir (Ertz, Karakas, \& Sarigollu, 2016; Smith \& Paladino, 2010; Roitner-Schobesberger et al., 2008). Penelitian Yadav dan Pathak (2016) menunjukkan bahwa niat menggunakan produk ramah lingkungan tidak hanya pada konsumen dewasa namun juga mulai diperkenalkan pada konsumen muda. Wier dan Calverley (2002) menyatakan bahwa ketertarikan konsumen pada produk ramah lingkungan meningkat pesat di beberapa negara industri selama sepuluh tahun terakhir, khususnya produk organik. Produk organik merupakan salah satu sektor pemasaran produk pangan yang meningkat sangat pesat di Eropa, Amerika 
INOBIS: Jurnal Inovasi Bisnis dan Manajemen Indonesia

Volume 1, Nomor 1, Desember 2017

Andhy Setyawan

Utara, Australia, dan Jepang (Makatouni, 2002). Tarkiainen dan Sundqvist (2005) meyakini bahwa pertumbuhan sektor produk organik sebagai salah satu bentuk produk ramah lingkungan akan semakin meningkat secara signifikan di masa yang akan datang.

Meningkatnya masalah lingkungan hidup dan isu keamanan pangan tidak hanya menguntungkan bagi pemasaran produk ramah lingkungan (Van Doorn \& Verhoef, 2011), tetapi juga meningkatkan ketertarikan publik dan media pada produk dan pengolahannya (Williamson, 2007). Di Indonesia, meningkatnya ketertarikan dan konsumsi produk ramah lingkungan masih jauh tertinggal dibandingkan dengan negara tetangga, seperti Thailand dan India (www.tribunnews.com, 2012). Selain itu, konsumsi terhadap produk konvensional masih lebih tinggi dibandingkan dengan produk ramah lingkungan (Sulaeman, 2007). Hal tersebut juga terjadi di negara-negara Eropa, meskipun sebagian besar konsumen memiliki sikap positif terhadap produk ramah lingkungan, tetapi pembelian produk ramah lingkungan masih rendah (Aertsens et al., 2009). Tingginya harga dan ketersediaan produk ramah lingkungan dipersepsikan sebagai kendala terbesar oleh konsumen dalam mengkonsumsi produk ramah lingkungan (Aertsens et al., 2011; Lea \& Worsley, 2005).

Upaya persuasif diharapkan mampu mempengaruhi persepsi utilitas seseorang untuk bersikap positif terhadap produk ramah lingkungan. Karena sikap pada umumnya memiliki karakteristik yang relatif konsisten dengan perilaku yang direfleksikan (Schiffman \& Kanuk, 2010: 246), maka sewajarnya jika perilaku yang positif dari seseorang terhadap produk organik ditimbulkan oleh sikap positif, misalnya dalam bentuk niat membeli maupun kemauan untuk membeli produk ramah lingkungan pada tingkat harga yang premium dibandingkan produk konvensional (Aertsens et al., 2011; Smith \& Paladino, 2010; Tarkiainen \& Sundqvist, 2005). Yiridoe et al. (2005) berargumen bahwa preferensi konsumen terhadap produk ramah lingkungan didasarkan pada persepsi utilitas yang lebih baik mengenai produk tersebut, seperti lebih aman dan sehat dikonsumsi, serta lebih ramah lingkungan.

Pembingkaian pesan merupakan salah satu bentuk upaya persuasif (Wood, 2000), yang dapat digunakan untuk mempengaruhi persepsi dan sikap seseorang terhadap produk ramah lingkungan. Istilah "pembingkaian" diperkenalkan oleh Tversky dan Kahneman (1981) untuk mendeskripsikan bahwa bentuk penyajian yang berbeda (secara positif atau negatif) suatu informasi atau permasalahan yang sama akan berpengaruh terhadap respon yang diberikan. Respon seseorang akan berbeda terhadap suatu informasi logis yang sebenarnya bersifat ekivalen apabila informasi tersebut disajikan secara berbeda (Corner \& Hahn, 2010; Braun et al., 1997).

Dalam konteks perilaku konsumen, Grewal et al. (1994) memberikan definisi pembingkaian pesan positif maupun negatif. Pembingkaian pesan positif didefinisikan sebagai komunikasi yang menekankan keunggulan suatu merek atau keuntungan potensial bagi konsumen dalam suatu situasi. Sebaliknya, pembingkaian pesan negatif didefinisikan sebagai komunikasi yang menunjukkan ketidakunggulan suatu merek atau kerugian potensial bagi konsumen dalam suatu situasi.

Menggunakan kombinasi dari perspektif ekonomi manajerial dan perilaku konsumen, penelitian konseptual berupa telaah pustaka ini berusaha merangkaikan peran pembingkaian pesan sebagai upaya persuasif untuk meningkatkan persepsi utilitas konsumen untuk meningkatkan preferensinya terhadap produk ramah lingkungan. Gambaran umum yang melatarbelakangi penulisan artikel konseptual ini sudah penulis paparkan pada sub-bab Pendahuluan. Selanjutnya penulis akan memaparkan mengenai sub-bab Metode Penelitian, Telaah Pustaka, Diskusi, dan akhirnya ditutup dengan Kesimpulan. 
INOBIS: Jurnal Inovasi Bisnis dan Manajemen Indonesia

Volume 1, Nomor 1, Desember 2017

Andhy Setyawan

\section{Metode penelitian}

Sebagaimana dituliskan pada bagian awal artikel, penelitian ini bertujuan memberikan telaah pustaka mengenai peran pembingkaian pesan sebagai upaya persuasif untuk meningkatkan persepsi utilitas produk ramah lingkungan. Pada dasarnya penelitian ini adalah kajian konseptual yang merupakan bentuk dari riset kualitatif yang memadukan perspektif ekonomi manajerial dengan perilaku konsumen dari perspektif manajemen pemasaran. Pada langkah pertama untuk mencapai tujuan penelitian ini dilakukan dengan mengumpulkan berbagai informasi yang bersumber dari penelitian terdahulu terkait dengan produk ramah lingkungan, pembingkaian pesan, preferensi konsumen serta utilitasnya. Langkah kedua setelah informasi terkumpul kemudian dilihat bagaimana konsumsi produk ramah lingkungan di Indonesia dibandingkan dengan produk konvensional, mengidentifikasi preferensi dan utilitas konsumen terhadap produk ramah lingkungan. Langkah selanjutnya menelaah penelitiaan terdahulu mengenai upaya persuasif dengan pembingkaian pesan serta relevansinya pada peningkatan persepsi utilitas konsumen produk ramah lingkungan. Langkah akhir yang dilakukan adalah merangkaikan berbagai perspektif telaah pustaka tersebut menjadi suatu rumusan yang diharapkan mampu memberikan wawasan untuk meningkatkan preferensi konsumen dalam mengkonsumsi produk ramah lingkungan.

\section{Telaah pustaka}

\section{Perilaku Konsumen dalam Perspektif Ekonomi Manajerial}

Dalam ranah ilmu ekonomi, individu dipandang makhluk yang memiliki keinginan yang tak terbatas. Manusia selalu menginginkan material yang lebih baik dari apa yang sudah ada sebelumnya. Analisis berdasarkan ilmu ekonomi menunjukkan bahwa individu cenderung memberikan prioritas pada keinginan yang paling mungkin diperoleh berdasarkan preferensi dari sejumlah alternatif yang tersedia (Brickley, Smith, \& Zimmerman, 2016: 15). Merujuk pada Thomas dan Maurice (2016: 160), prinsip dasar dalam melakukan analisis perilaku konsumen dari sudut pandang ekonomi manajerial adalah bahwa semua individu melakukan keputusan konsumsi dengan memaksimalkan total kepuasan yang diperoleh dari kegiatan konsumsi berbagai barang dan jasa, dengan mempertimbangkan bahwa fungsi kendala dalam membelanjakan barang dan jasa tersebut harus sama dengan penghasilan yang dimiliki individu tersebut.

Guna memenuhi tujuan memaksimalkan total kepuasan dari konsumsi produk (barang dan atau jasa), konsumen akan selalu membandingkan produk dengan berbagai alternatif yang tersedia. Konsumen akan membandingkan tingkat kepuasan yang diperoleh dari suatu produk relatif terhadap harganya, apakah produk tersebut cukup bernilai untuk dibeli. hal inilah kemudian yang melahirkan konsep utilitas. Merujuk pada Graham (2013: 74), secara sederhana utilitas didefinisikan sebagai sejumlah kepuasan yang dirasakan konsumen setelah mengkonsumsi suatu produk. Dengan demikian preferensi konsumen terhadap suatu produk sangat bergantung pada nilai utilitas yang dirasakan. Selama suatu produk dinilai memberikan utilitas yang lebih tinggi, maka konsumen akan cenderung memilih produk tersebut untuk memaksimalkan total kepuasannya.

Schiffman dan Kanuk (2010: 23) mendefinisikan perilaku konsumen sebagai suatu perilaku yang ditunjukkan oleh konsumen dalam mencari, membeli, menggunakan, mengevaluasi, dan menempatkan produk (barang dan jasa) yang diharapkan mampu memberikan kepuasan pada kebutuhannya. Foxall (2001) menyarankan bahwa analisis perilaku konsumen tidak hanya dilakukan dengan pendekatan keperilakuan saja, namun juga 
INOBIS: Jurnal Inovasi Bisnis dan Manajemen Indonesia

Volume 1, Nomor 1, Desember 2017

Andhy Setyawan

dengan berbagai pendekatan yang relevan seperti pendekatan konsumsi secara ekonomis. Perilaku konsumen berfokus pada bagaimana konsumen individu maupun kelompok membuat keputusan untuk menggunakan berbagai sumber daya yang dimiliki untuk mengkonsumsi produk yang memberikan nilai utilitas maksimal.

Memahami perilaku konsumen adalah langkah awal dalam menentukan tingkat harga produk yang menguntungkan, periklanan yang berdampak, desain produk yang sesuai dengan selera konsumen, dan keputusan produksi lainnya. Pihak manajemen memerlukan model ekonomi yang tepat dari perilaku konsumen untuk dapat memberikan estimasi yang tepat terhadap produk yang sesuai dengan kebutuhan dan keinginan konsumen serta memaksimalkan utilitas (Thomas \& Maurice, 2016: 159). Apabila pihak manajemen mampu mengistimasi secara akurat perilaku konsumen yang menjadi target pasarnya, maka peluang untuk memuaskan kebutuhan dan keinginan konsumen semakin besar, yang juga menunjukkan semakin besarnya peluang sukses suatu bisnis (Graham, 2013: 73). Pengambilan keputusan manajerial yang mampu memberikan utilitas maksimal pada konsumen merupakan elemen penting dalam ekonomi manajerial. Pemahaman yang tepat pada karakteristik dan perilaku konsumen juga memberikan manfaat bagi pihak manajemen untuk merancang berbagai cara dalam mempengaruhi preferensi konsumen.

\section{Pembingkaian Pesan}

Merujuk pada Wood (2000), perubahan persepsi atau sikap individu dapat ditimbulkan oleh upaya persuasi dan pengaruh sosial. Persuasi merupakan topik terbesar dalam literatur mengenai sikap (Olson \& Zanna, 1993). Persuasi dapat didefinisikan sebagai pembentukan atau perubahan sikap melalui pemrosesan informasi sebagai bentuk respon terhadap pesan yang berkaitan dengan sikap terhadap suatu objek (Bohner et al., 2008b dalam Bohner \& Dickel, 2011). Persuasi berkaitan erat dengan upaya aktif yang dilakukan untuk mengubah sikap (Solomon, 2011: 297). Pembingkaian pesan merupakan salah satu bentuk persuasi (Wood, 2000), yang mana merupakan konsep utama yang diteliti dalam artikel ini.

Teori prospek (Kahneman \& Tversky, 1979) merupakan landasan teoritis yang digunakan untuk menjelaskan efek dari pembingkaian. Efek pembingkaian yang dimaksud adalah bahwa seseorang akan merespon berbeda informasi yang dibingkai secara berbeda (positif atau negatif), meskipun informasi tersebut sebenarnya sama. Berdasarkan pada Tversky dan Kahneman (1981), pembingkaian positif menekankan aspek manfaat (keuntungan) yang diperoleh jika melakukan pesan yang dikomunikasikan, sedangkan pembingkaian negatif menekankan aspek risiko (kerugian) yang ditanggung apabila tidak melakukan pesan yang dikomunikasikan.

Penelitian-penelitian mengenai pembingkaian pesan memberikan hasil yang bervariasi (misal, lihat Levin et al., 1998) bergantung pada kasus yang diteliti dan orientasi dalam penyampaian pesan berkaitan dengan perilaku hidup sehat, yaitu bersifat pencegahan atau deteksi (Chang, 2007; Arora et al., 2006). Hasil penelitian yang berbeda juga bisa disebabkan karena jenis pembingkaian yang diterapkan (Levin et al., 1998), serta adanya variabel-variabel moderasi, seperti keterlibatan (contoh, Maheswaran \& Meyers-Levy,1990), perhatian mengenai perubahan iklim global (Newman et al., 2012), construal level (White et al., 2011), perbedaan individu (contoh, Simon et al., 2004), need for cognition (misal, Zhang \& Buda, 1999), kredibilitas sumber (misal, Buda \& Zhang, 2000), perceived efficacy (Block \& Keller, 1995).

Penelitian mengenai pembingkaian pesan juga dapat dijumpai pada literatur terkait isu keberlanjutan dan lingkungan hidup. Hasil penelitian menunjukkan keefektifan pembingkaian pesan secara positif maupun negatif yang berbeda-beda antar penelitian. 
INOBIS: Jurnal Inovasi Bisnis dan Manajemen Indonesia

Volume 1, Nomor 1, Desember 2017

Andhy Setyawan

Penelitian yang dilakukkan oleh Davis (1995) menunjukkan pembingkaian pesan negatif lebih efektif mempengaruhi niat seseorang untuk berpartisipasi dalam perilaku yang bertanggungjawab terhadap lingkungan hidup (dioperasionalkan sebagai konservasi, daur ulang, dan green shopping). Hasil penelitian tersebut didukung oleh hasil penelitian Newman et al. (2012) yang juga menunjukkan pembingkaian negatif lebih persuasif pada individu yang memiliki perhatian (concern) rendah terhadap isu perubahan iklim global, dalam konteks pesan mengenai keberlanjutan lingkungan hidup. Hasil kontradiktif mengenai keefektifan pembingkaian pesan ditunjukkan oleh penelitian Van de Velde et al. (2010) mengenai aspekaspek keberlanjutan dan lingkungan dari energi. Kesimpulan menyeluruh dari penelitian Van de Velde et al. (2010) menyatakan bahwa pembingkaian pesan positif yang berfokus pada berbagai peluang dan solusi masalah, seperti penghematan penggunaan energi atau penggunaan sumber energi yang lebih ramah lingkungan, akan lebih efektif mengajak orangorang untuk berkontribusi mencegah dan mengurangi permasalahan energi dan lingkungan hidup. Disamping penelitian-penelitian yang menonjolkan keefektifan pembingkaian positif atau negatif tersebut, penelitian Setyawan (2014) justru menunjukkan hasil yang berbeda, yaitu tidak ada perbedaan sikap terhadap produk ramah lingkungan pada individu yang mendapat perlakuan pembingkaian pesan positif maupun pembingkaian pesan negatif, namun terdapat interaksi yang signifikan antara pembimgkaian pesan dengan keterlibatan individu terhadap isu mengenai keberlanjutan lingkungan hidup.

Tinjauan literatur mengenai efek pembingkaian pesan yang dipaparkan sebelumnya memberikan dukungan bahwa keefektifan antara pembingkaian positif maupun pembingkaian negatif dalam mempengaruhi keputusan sangat bervariasi. Levin et al. (1998) berpendapat bahwa hasil yang bervariasi tersebut disebabkan oleh perbedaan jenis pembingkaian yang digunakan. Berdasarkan kajian terhadap penelitian-penelitian yang dilakukan sebelumnya mengenai pembingkaian, Levin et al. (1998) menggolongkan pembingkaian menjadi tiga jenis, yaitu berdasarkan kriteria: (1) apa yang dibingkai; (2) apa yang dipengaruhi; dan (3) bagaimana efek pembingkaian diukur. Tiga jenis pembingkaian yang dimaksud adalah pembingkaian pilihan berisiko (risky choice framing), pembingkaian atribut (attribute framing), dan pembingkaian tujuan (goal framing).

\section{Diskusi}

Berdasarkan penjabaran yang ada pada bagian pendahuluan dan telaah pustaka, masalah yang diteliti dalam penelitian terkait dengan masalah teoritis dan masalah praktis. Masalah teoritis merujuk pada masih sedikitnya penelitian yang membahas mengenai upaya persuasif yang dapat dilakukan pemasar untuk meningkatkan minat masyarakat untuk menggunakan produk ramah lingkungan, serta inkonsistensi hasil penelitian sebelumnya terkait peran pembingkaian pesan dalam memberikan efek persuasi guna meningkatkan persepsi utilitas konsumen untuk menggunakan produk ramah lingkungan.

Masalah praktis penelitian adalah adanya fenomena konsumsi produk ramah lingkungan yang masih rendah dibandingkan dengan produk konvensional (Aertsens et al., 2009; Sulaeman, 2007; www.tribunnews.com, 2012). Perhatian dan konsumsi terhadap produk ramah lingkungan merupakan salah satu upaya yang dapat dilakukan untuk mengurangi proses penurunan kualitas lingkungan hidup dan kesehatan. Penelitian konseptual ini mencoba merangkaikan perspektif ekonomi manajerial dan perilaku konsumen dalam konsumsi produk ramah lingkungan.

Perubahan permintaan dan perilaku konsumen pada produk ramah lingkungan (Mendleson dan Polonsky, 1995) belumlah cukup untuk menjawab isu keberlanjutan lingkungan hidup. Fakta yang ada masih menunjukkan bahwa konsumsi produk konvensional 
INOBIS: Jurnal Inovasi Bisnis dan Manajemen Indonesia

Volume 1, Nomor 1, Desember 2017

Andhy Setyawan

masih lebih banyak dibandingkan produk yang ramah lingkungan (Aertsens et al., 2009; Sulaeman, 2007; www.tribunnews.com, 2012). Sebagian besar konsumen mempersepsikan bahwa konsumsi produk konvensional memberikan utilitas yang lebih tinggi dibandingkan produk ramah lingkungan. Kendala penghasilan masyarakat Indonesia yang masih rendah menyebabkan sebagian besar masyarakat harus merasa puas dengan produk konvensional yang menawarkan harga yang lebih murah dan ketersediaan yang lebih banyak. Hal ini sejalan dengan sudut pandang ilmu ekonomi, bahwa individu memenuhi kebutuhan konsumsi dengan utilitas maksimal berdasarkan pertimbangan kendala penghasilan yang dimiliki (Thomas \& Maurice, 2016: 160).

Masalah utama yang dihadapi dalam memasarkan produk ramah lingkungan adalah tingginya harga dan ketersediaan produk (Aertsens et al., 2011; Lea \& Worsley, 2005). Tingginya harga akan menjadi fungsi kendala yang bersesuaian dengan tingkat penghasilan konsumen, karena konsumen tidak mungkin mengkonsumsi produk yang melebihi nilai penghasilannya. Meskipun demikian, Padel dan Foster (2005) berpendapat bahwa kemungkinan konsumen untuk memiliki kemauan membeli produk ramah lingkungan akan lebih tinggi jika mereka menyadari berbagai alasan dibalik tingginya harga produk ramah lingkungan tersebut. Karena itu, upaya-upaya pemasar untuk meningkatkan persepsi dan sikap positif terhadap produk ramah lingkungan tentunya sangat diperlukan. Pemasar perlu melakukan edukasi untuk mengubah persepsi utilitas produk ramah lingkungan menjadi lebih baik dibandingkan produk konvensional, sehingga preferensi konsumen terhadap produk ramah lingkungan menjadi tinggi.

Dalam bahasan produk ramah lingkungan, Yiridoe et al. (2005) menjelaskan bahwa preferensi konsumen terhadap produk ramah lingkungan didasarkan pada sikap terhadap karakteristik yang dimiliki produk ramah lingkungan tersebut, seperti lebih aman dan sehat dikonsumsi, serta lebih ramah lingkungan. Upaya persuasif dengan pembingkaian pesan dapat dilakukan untuk memberikan edukasi kepada konsumen bahwa produk ramah lingkungan menawarkan nilai utilitas yang lebih tinggi dibandingkan produk konvensional. Komunikasi pemasaran yang efektif melalui pembingkaian pesan ini diharapkan mampu meningkatkan persepsi utilitas konsumen terhadap produk ramah lingkungan, sehingga pada akhirnya mampu meningkatkan konsumsi produk ramah lingkungan dibandingkan produk konvensional.

Proses persuasif dengan pembingkaian pesan juga perlu mempertimbangkan target konsumennya. Target konsumen yang diprioritaskan tentunya adalah segmen konsumen yang memiliki daya beli terlebih dahulu. Kemudian upaya persuasif tersebut perlu dievaluasi terus menerus bahkan dikembangkan ke segmen konsumen yang lebih luas lagi. Selain itu, pemasar juga perlu lebih kreatif dan inovatif dalam menawarkan produk ramah lingkungan sehingga kendala harga dan ketersediaan dapat diatasi dengan baik.

\section{Kesimpulan}

Perhatian dan konsumsi terhadap produk yang ramah lingkungan, khususnya produk organik merupakan salah satu upaya yang dapat dilakukan untuk mengurangi proses penurunan kualitas lingkungan hidup dan kesehatan. Menggunakan kombinasi dari perspektif ekonomi manajerial dan perilaku konsumen, penelitian konseptual berupa telaah pustaka ini berusaha merangkaikan peran pembingkaian pesan sebagai upaya persuasif untuk meningkatkan persepsi utilitas konsumen untuk meningkatkan preferensinya terhadap produk ramah lingkungan.

Pembingkaian pesan dalam komunikasi pemasaran dapat digunakan sebagai salah satu upaya untuk mempersuasi konsumen untuk mengkonsumsi produk ramah lingkungan 
INOBIS: Jurnal Inovasi Bisnis dan Manajemen Indonesia

Volume 1, Nomor 1, Desember 2017

Andhy Setyawan

dibandingkan dengan produk konvensional. Pembingkaian pesan diharapkan mampu meningkatkan persepsi utilitas konsumen pada produk ramah lingkungan, misalnya lebih aman dan sehat dikonsumsi, serta lebih ramah lingkungan demi masa depan lingkungan hidup yang lebih baik. Peningkatan persepsi utilitas konsumen pada produk ramah lingkungan ini secara teoritis akan menggeser preferensi konsumen untuk lebih banyak mengkonsumsi produk ramah lingkungan.

Demikianlah investigasi yang penulis lakukan mengenai keterkaitan pembingkaian pesan, fungsi utilitas dan preferensi konsumen pada produk ramah lingkungan, semoga dapat menambah wawasan dan bermanfaat bagi kita semua.

\section{Daftar referensi}

Aertsens, J., Mondelaers, K., Verbeke, W., Buysse, J., \& Van Huylenbroeck, G. 2011. The influence of subjective and objective knowledge on attitude, motivations and consumption of organic food. British Food Journal, 113: 1353-1378.

Aertsens, J., Verbeke, W., Mondelaers, K., \& Van Huylenbroeck, G. 2009. Personal determinants of organic food consumption: A review. British Food Journal, 111: 1140-1167.

Arora, R., Stoner, C., \& Arora, A. 2006. Using framing and credibility to incorporate exercise and fitness in individuals' lifestyle. Journal of Consumer Marketing, 23: 199-207.

Block, L. G., \& Keller, P. A. 1995. When to accentuate the negative: The effects of perceived efficacy and message framing on intentions to perform a health-related behavior. Journal of Marketing Research, 32: 192-203.

Bohner, G., \& Dickel, N. 2011. Attitudes and attitude change. Annual Review of Psychology, 62: 391-417.

Braun, K. A., Gaeth, G. J., \& Levin, I. P. 1997. Framing effects with differential impact: The role of attribute salience. Advances in Consumer Research, 24: 405-411.

Brickley, J. A., Smith, C. W., \& Zimmerman, J. L. 2016. Managerial economics and organizational architecture (6th ed.). New York, NY: McGraw-Hill.

Buda, R., \& Zhang, Y. 2000. Consumer product evaluation: The interactive effect of message framing, presentation order, and source credibility. Journal of Product \& Brand Management, 9: 229-242.

Chang, C. T. 2007. Health-care product advertising: The influences of message framing and perceived product characteristics. Psychology \& Marketing, 24: 143-169.

Corner, A., \& Hahn, U. 2010. Message framing, normative advocacy and persuasive success. Argumentation, 24: 153-163.

Davis, J. J. 1995. The effects of message framing on response to environmental communications. Journalism and Mass Communication Quarterly, 72: 285-299.

Ertz, M., Karakas, F., \& Sarigöllü, E. 2016. Exploring pro-environmental behaviors of consumers: An analysis of contextual factors, attitude, and behaviors. Journal of Business Research, 69: 3971-3980.

Foxall, G. R. 2001. Foundations of consumer behaviour analysis. Marketing Theory, 1: 165199.

Graham, R. 2013. Managerial economics for dummies. Hoboken, NJ: John Wiley \& Sons, Inc.

Grewal, D., Gotlieb, J., \& Marmorstein, H. 1994. The moderating effects of message framing and source credibility on the price-perceived risk relationship. Journal of Consumer Research, 21: 145-153. 
INOBIS: Jurnal Inovasi Bisnis dan Manajemen Indonesia

Volume 1, Nomor 1, Desember 2017

Andhy Setyawan

Haytko, D. L., \& Matulich, E. 2008. Green advertising and environmentally responsible consumer behaviors: Linkages examined. Journal of Management and Marketing Research, 1: 5-14.

Kahneman, D., \& Tversky, A. 1979. Prospect theory: An analysis of decision under risk. Econometrica, 47: 263-292.

Lea, E., \& Worsley, T. 2005. Australians' organic food beliefs, demographics and values. British Food Journal, 107: 855-869.

Lehman, P. K., \& Geller, E. S. 2004. Behavior analysis and environmental protection: Accomplishment and potential for more. Behavior and Social Issues, 13: 13-32.

Levin, I. P., Schneider, S. L., \& Gaeth, G. J. 1998. All frames are not created equal: A typology and critical analysis of framing effects. Organizational Behavior and Human Decision Processes, 76: 149-188.

Maheswaran, D., \& Meyers-Levy, J. 1990. The influence of message framing and issue involvement. Journal of Marketing Research, 27: 361-367.

Makatouni, A. 2002. What motivates consumers to buy organic food in the UK? Results from a qualitative study. British Food Journal, 104: 345-352.

Mendleson, N., \& Polonsky, M. J. 1995. Using strategic alliances to develop credible green marketing. Journal of Consumer Marketing, 12: 4-18.

Newman, C. L., Howlett, E., Burton, S., Kozup, J. C., \& Tangari, A. H. 2012. The influence of consumer concern about global climate change on framing effects for environmental sustainability messages. International Journal of Advertising, 31: 511-527.

Olson, J. M., \& Zanna, M. P. 1993. Attitudes and attitude change. Annual Review of Psychology, 44: 117-154.

Padel, S., \& Foster, C. 2005. Exploring the gap between attitudes and behavior: Understanding why consumers buy or do not buy organic food. British Food Journal, 107: 606-625.

Roitner-Schobesberger, B., Darnhofer, I., Somsook, S., \& Vogl, C. R. 2008. Consumer perceptions of organic foods in Bangkok, Thailand. Food Policy, 33: 112-121.

Schiffman, L. G., \& Kanuk, L. L. 2010. Consumer behavior (10th ed.). Upper Saddle River, NJ: Pearson Education, Inc.

Setyawan, A. 2014. Message framing and involvement in influencing attitudes towards organic products. Manajemen \& Bisnis Berkala Ilmiah, 13: 150-160.

Simon, A. F., Fagley, N. S., \& Halleran, J. G. 2004. Decision framing: Moderating effects of individual differences and cognitive processing. Journal of Behavioral Decision Making, 17: 77-93.

Smith, S., \& Paladino, A. 2010. Eating clean and green? Investigating consumer motivations towards the purchase of organic food. Australasian Marketing Journal, 18: 93-104.

Solomon, M. R. 2011. Consumer behavior: Buying, having, and being (9th ed.). Upper Saddle River, NJ: Pearson Education, Inc.

Steg, L., \& Vlek, C. 2009. Encouraging pro-environmental behaviour: An integrative review and research agenda. Journal of Environmental Psychology, 29: 309-317.

Sulaeman, A. 2007. Prospek pasar dan kiat pemasaran produk pangan organik. Simposium ISSAAS Indonesian Chapter, Bogor, Indonesia.

Tarkiainen, A., \& Sundqvist, S. 2005. Subjective norms, attitudes and intentions of Finnish consumers in buying organic food. British Food Journal, 107: 808-822.

Thomas, C. R., \& Maurice, S. C. 2016. Managerial economics: Foundations of business analysis and strategy (12th ed.). New York, NY: McGraw-Hill. 
INOBIS: Jurnal Inovasi Bisnis dan Manajemen Indonesia

Volume 1, Nomor 1, Desember 2017

Andhy Setyawan

Tversky, A., \& Kahneman, D. 1981. The framing of decisions and the psychology of choice. Science, 211: 453-458.

Van de Velde, L., Verbeke, W., Popp, M., \& Van Huylenbroeck, G. 2010. The importance of message framing for providing information about sustainability and environmental aspects of energy. Energy Policy, 38: 5541-5549.

Van Doorn, J., \& Verhoef, P. C. 2011. Willingness to pay for organic products: Differences between virtue and vice foods. International Journal of Research in Marketing, 28: 167-180.

White, K., Macdonnell, R., \& Dahl, D. W. 2011. It's the mind-set that matters: The role of construal level and message framing in influencing consumer efficacy and conservation behaviors. Journal of Marketing Research, 48: 472-485.

Wier, M., \& Calverley, C. 2002. Market potential for organic foods in Europe. British Food Journal, 104: 45-62.

Williamson, C. S. 2007. Is organic food better for our health? Nutrition Bulletin, 32: 104108.

Wood, W. 2000. Attitude change: Persuasion and social influence. Annual Review of Psychology, 51: 539-570.

Yadav, R., \& Pathak, G. S. 2016. Young consumers' intention towards buying green products in a developing nation: Extending the theory of planned behavior. Journal of Cleaner Production, 135: 732-739.

Yiridoe, E. K., Bonti-Ankomah, S., \& Martin, R. C. 2005. Comparison of consumer perceptions and preference toward organic versus conventionally produced foods: A review and update of the literature. Renewable Agriculture and Food Systems, 20: 193-205.

Zhang, Y., \& Buda, R. 1999. Moderating effects of need for cognition on responses to positively versus negatively framed advertising messages. Journal of Advertising, 28: $1-15$.

www.tribunnews.com/2012/06/12/cara-meningkatkan-daya-jual-produk-organik 